\title{
Applicability of Legal Norms in Resolving the Commercial Disputes
}

\author{
Erjola Aliaj \\ European University of Tirana \\ Email:aerjola@gmail.com
}

\section{Doi:10.5901/mjss.2014.v5n23p72}

\begin{abstract}
Commercial activity is the heart of the market economy system. In a democracy, freedom of initiative in the commercial field is one of the rights guaranteed to the legal entities. The exercise of this activity, as well as the many other activities that take place in commercial company, is regulated by the legal rules that create a favorable business and incentives climate for the development of economic activities, directly affecting the country's economic growth. New economic developments in the country as well as compelling to bring our commercial legislation in alignment with that of the European Union, makes to arise the need for adopting a new law "On Entrepreneurs and Companies", which will reflect the best experience of European Union countries, in the light of adjustments to EU legislation, whether primary (treaties) or secondary (regulations or directives). Since the legislation in the commercial field is "new", during this period of its implementation (2008-2014) were identified ambiguities, lack of commercial provisions and a unified judicial practice, which would come to help to the commercial companies in evaluating the decisions of its governing organs. Precisely, through this paper is aimed the identification of these problems and possibility to offer potential solutions.
\end{abstract}

Keywords: commercial law, commercial company, decision, dispute.

\section{Introduction}

Interest of the commercial company is closely linked to the sustainability of its bodies' decisions, for not being constantly exposed to seeking the nullity of anyone concerned and remains therefore in a state of permanent insecurity. Also, the interests of third parties are focused on eliminating every obstacle that would bring uncertainty about the validity of previous decisions.

In this situation, it is important to define clear legal rules for the form or manner of objection of the decision of the assembly, for having violated the law, statute or did not respect other legal requirements.

Uncertainties or gaps identified during the implementation of trade legislation in this field have led to an increase of conflicts within the company as well as in the expansion of the problem, except in practical terms and in that theoretical.

Enforcement of Law No.9901 dated 14.04.2008 "On Entrepreneurs and Companies" has also shown different views on judicial practice regarding problems arising as a result of scarcity and uncertainty of legal norms.

The purpose of this paper is to address the way of commercial law application in settling disputes, analyzing commercial provisions and case law.

The objectives of this paper are the identification of uncertainties and gaps in commercial law, evaluation of solutions provided by case law and the proposal, in case of absence, for the implementation of any legal provision.

\section{Application of Commercial Law in Resolving the Commercial Disputes}

In terms of Law No. 9901, dated 14.04.2008 "On Entrepreneurs and Companies", the Assembly is the gathering of all partners / shareholders of the company in order to show the will of the commercial company. It is conscience of commercial company partners to act within the view of the company.

Assembly is in fact "the highest body" of company because of its powers to adopt, amend, and modify the statute of the company. The law sets a strong position to the assembly of shareholders, as the only body which directly appoints and dismisses the governing bodies of the company. However, the assembly is obliged to respect legal norms regarding the structure of company, its functioning and the interests of minority shareholders.

Law No. 9901, dated 14.04.2008 "On Entrepreneurs and Companies", contains detailed rules, dealing with the decision-making procedure of the highest body of company, dealing with the calling of the meeting, a quorum of shareholders present in decision-making, the kind of decisions that require a majority of the votes and ordinary decisions 
requiring a qualified majority, and the amount of votes that are enough to make any decision.

Current Law No.9901 dated 14.04.2008 "On Entrepreneurs and Companies" does not contain any provision regarding challenging a decision of the assembly of partners / shareholders for the cause that this decision violates the law, statute or procedure of call etc. The absence of a provision to challenge unlawful decisions of the majority reflected in a decision of assembly, can lead to problems mainly for the protection of minority of shareholders / shareholders but not only (Bachner, Th.,\& Schuster, E.,\& Winner, M. 2009).

The question arises: How can be objected the decision of assembly for nullity or avoidance?

If we refer for analogy to Italian legislation, article 2373 of the Italian Civil Code provides that the decision is challenged "if the damage is caused to company ". I.e. the decision is voidable if it turns and it is evident that is being sacrificed the interest of company. The above-mentioned article does not require damage suffered by the company but only to be proved the existence of risk to suffer damage. (Galgano, F. 2009).

Albanian court practice has moved in the direction of resolving these disputes based on the provisions of article 92 of Albanian Civil Code on the invalidity of legal acts (Dylqeshi, E., \& Dylqeshi, L., \& Dylqeshi, B., \& Shima, Z., \& Shima,A., \& Lushi,P., \& Shima, L., \& Kurdari,L. \& Kurdari,E. vs Riparim Makineri, 2011), (Kurti, B. vs shoqeria Sport Point sh.p.k., 2013).

Also, in most of the decisions of Tirana District Court, is ascertained that judges to resolve the disputes between the partners apply the old law On Commercial Companies despite the fact that the lawsuits in court have been filed and court proceeding is been held after the entry into force of the new law.

Judicial activity consists in the implementation of legal provisions on specific concrete issues. In any case, when the exercised case is not regulated in concrete terms, judges must make every effort to refer the most appropriate norms to be applied in order to solve the trade dispute, guided by the basic principles of commercial law. (Dine, J., \& Blecher, M., \& Hoxha, Sh., \& Race, B. 2008).

The current law "On Entrepreneurs and Companies" has two transitional provisions that speak for existing companies and the application of this law to the following procedures. Thus, under a plain reading of article 230 is reached in conclusion that their statute would apply despite the fact that it may come in conflict with the new law. Continuation of this provision is that commercial companies that existed before its entry into force are obliged to adapt their organization and functioning under the provisions of this law within three years after its entry into force. However, for situations that are not regulated by the statute automatically apply the new law.

According to article 231, the provisions of this Law apply to the procedure for establishment or change of a founder, shareholder or partner of the company, the election procedures of the bodies, the adoption of regulations or statutes and other organizational procedures, initiated at the time of entry into force of the law.

The general principle is that laws are applicable and extend their effects for the legal relations arising after their entry into force (Albanian National Association of Soldiers, 2007). Theory of law acknowledges that retroactive exemption applies to as an exception, for example, criminal laws favorable, the laws that interfere to regulate illegal situation created earlier, in interpreting laws or dark sides of a vague previous law and in any other case where the need appears to avoid serious, negative or irreparable consequences (Malltezi, A. 2011).

\subsection{Judicial Practice}

Regarding the applicability by the courts of the old law at a time when the current law could be applied retroactively and the effects of the transitional provisions, we bring as illustration:

1. Decision no. 3417 dated 10/04/2012 of Tirana District Court.

Circumstances of the case

Company "MANIFACTURE.ITALIANA" Ltd, is owned by partners C.C. (the plaintiff) and M.R.T. (the defendant), who own in equity equally participation quota, with $50 \%$ each.

Since May, 2009, in this company, statutory changes are made passing from the management of the company with one administrator into administration with two co-administrators of inherent and equal powers between them and precisely company has as co-administrators the plaintiff C.C. and the defendant M.R.T.

It turns out that on 24.12.2009 for implementation of a new shed in Xhaf-Zotaj (Durres), the company has received a bank loan amounting to $€ 1,300,000$.

According to the minutes of the assembly of shareholders of this company, from 22 June 2010 till 12.01 .2011 have been called several meeting of assembly of shareholders, mainly for financial problems; and for various reasons, the problems are not exhausted until was called the assembly of partners as of 12.01 .2012 (subject of this trial), which among other issues addressed: Reducing the costs of co-administrators at 70\%; Taking disciplinary measure for 
dismissal of the co-administrator M.R.T as well as the remuneration of the damage caused to the company as a result of financial abuses.

It has resulted that in this meeting by the assembly of shareholders have not been approved both these agenda items proposed by the partner C.C. and in these conditions, disagreeing with this view held by the shareholders assembly, plaintiff addressed a lawsuit to this Court, seeking the settlement of this conflict, subject to commercial law, in relation to the partial invalidation of the General Assembly decision and the consequences that derive from this invalidation.

The Court argues that:

\begin{abstract}
Referring to the provisions of article 231 of Law no. 9901, dated 14.04.2008 "On Entrepreneurs and Companies" the 3year period allows commercial entities to continue their activity on the basis of regulatory law. This provision stipulates that.... entities that existed prior to the enactment of this law are obliged to adapt their organization under the provisions of this law within three years after entry into force ... those companies that do not fit within this period are liquidated and deregistered from NRC.
\end{abstract}

The Court therefore reached to the conclusion that in reviewing the lawsuit and the demands that are presented regarding the alleged invalidity, the applicable law will be Law no. 7638, dated 19.11.1992 "On commercial companies". In reaching this conclusion, the Court takes into consideration the fact, that explicitly, the new law in its transitional provisions of this specification has retroactive effects.

While the settlement of binding consequences for the counterparties must be done to respect and compliance of Article 231 of Law no. 9901, dated 14.04.2008, whereof is expressly sanctioned: that this law would apply to the settlement procedures of approval bodies, regulation or ordinance, other organizational procedures initiated at the time of entry into force of this law ...

In reaching this conclusion, this Court has taken into consideration even the fact that company after filing the respective lawsuit in May 2011 has approved the adjustment of the statute of the company with the new law in accordance with the provisions of Article 230 paragraph 3 of this Law.

In the present case, the court should not enforce the old law as long as the relationship between the parties or better say the dispute between the parties had arisen after the entry into force of the new law, was not regulated by the statute and only foundation of the commercial company had occurred before the entry into force of the new law.

2. Decision no. 8496 dated $24 / 092012$ of Tirana District Court.

Circumstances of the case

The company "Projeksion Energji" join stock company, is owned by shareholders A.R. (the plaintiff) and S.R. (third person), who possess equally by $50 \%$ of the shares each. This company has two-tier management system, which means that the Supervisory Council appoints and dismisses its administrators and as for the hierarchy supervises the work of the administrator of the company. On 24.11.2011, the Supervisory Board in the presence of two members only, SR and E.R. has taken the decision to discharge the administrator A.R. and has appointed as administrator O.P. On 25.11.2011, the decision of the Supervisory Council of the commercial company is initially registered at the National Registration Center. On 07.12.2011, based on the claim letter of A.R. (the plaintiff), the General Director of the National Registration Center repealed the registration of the decision, which appointed O.P. as administrator of the company. The plaintiff filed a lawsuit, claiming the absolute invalidity of the Supervisory Council Decision, since the nomination term of the Supervisory Council has expired and that the members of the Supervisory Council have inconsistencies in their capacity as members as they are parents and spouses of the two shareholders.

The Court argues that:

In the present case, although the law provides a three-year term for the Supervisory Council, as long as this commercial company has a two-tier management system defined in its statute and as long as the General Assembly does not result to be convened for the appointment of the new members of the Supervisory Council, then their mandate would be continuous, because it cannot be infringed the principle of the type of administration chosen by statute (two-tier management system) due to the inaction of the General Assembly on the election of the new members of Supervisory Council.

As regards to the claim of the plaintiff that in the composition of the members of Supervisory Council has persons who have functional inconsistencies that are in violation of article 167 and 13 of Law "On Entrepreneurs and Companies", the Court appraises that referring to articles 230 and 231 of the abovementioned Law, the commercial companies within 
three years from the entry into force of this law, must adapt the company's statute with the new law. Incompatibility and cases when the election procedures of governing bodies are not in compliance with this law bring to deregistration of these companies from the register of the NRC after the completion of the liquidation procedure.

Consequently, the court can not declare the invalidity of the decisions of a company's body, which was established in violation of the law, and thus legitimize the illegality of the functionality's way of a commercial company, where the consequences for such an organization are expressly provided by law.

In the present case, despite the fact that the company has not adapted the statute with law No.9901 dated 14.04.2008 "On Entrepreneurs and Companies", the Court should apply the provisions of this law ascertaining the invalidity of the Supervisory Council's decision due to its term beyond of that of three years, but even to the members conflict with the ruling provisions of the new law.

\section{Conclusions / Recommendations}

The old law no. 7638, dated 19.11.1992 "On commercial companies" should not apply as long as the dispute between the parties has arisen after the entry into force of the new law, even if it is not regulated by the statute and only the foundation of the company has occurred before entry into force of Law no. 9901, dated 14.04.2008 "On Entrepreneurs and Companies".

Provisions of Law no. 9901, dated 14.04.2008 "On Entrepreneurs and Companies" shall apply to disputes between the parties arising after the entry into force of the law, despite the fact that company has not adapted its Statute to Law No.9901 dated 14.04.2008 "On Entrepreneurs and Companies ".

Disputes about the illegal decision-making of the partners/shareholders, cannot be resolved based on the provisions of article 92 of the Civil Code, concerning the invalidity of legal acts but based on the provisions of article 93 of Law No. 9901 dated 14.04.2008 " On Entrepreneurs and Companies " to prohibit the infringement or compensation for damage caused as a result of violation of the right of quota.

Disputes about the illegal decision-making of the partners/shareholders, can be opposed even if it is proved the existence of the risk of damage to be suffered by the company.

\section{References \\ Court decisions}

Decision No. 9, dated 26.02.2007 of Tirana District Court Decision No. 8496 Dated 24.09.2012 of Tirana District Court Decision no. 3417 Dated 10.04.2012 of Tirana District Court Decision no.10771 dated. 27.12.2011 of Tirana District Court Decision no.1823 dated. 28.02.2013 of Tirana District Court

\section{Legislation}

Law No.7638, dated 19.11.1992, "On commercial companies". Law No. 9901, dated 14.04.2009, "On Entrepreneurs and Companies". Civil Code of the Republic of Italy.

\section{Monographies}

Bachner, Th.,\& Schuster, E.,\&Winner, M. (february 2009). The new Albanian law "On companies" interpreted according to its sources in European law. Dudaj publications.

Dine, J., \& Blecher, M., \& Hoxha, Sh., \& Race, B. (february 2008). The New Law on Entrepreneurs and Companies - commentary. Galgano, F. (2009). The commercial law. Entrepreneurs - commercial companies. Luarasi University Press. Malltezi, A. (2011). Albanian law of commercial companies. Mediaprint publishing house. 